\title{
Induction of Resistance to Penicillium digitatum in Grapefruit by the Yeast Biocontrol Agent Candida oleophila
}

\author{
S. Droby, V. Vinokur, B. Weiss, L. Cohen, A. Daus, E. E. Goldschmidt, and R. Porat
}

First, second, third, fourth, fifth, and seventh authors: Department of Postharvest Science of Fresh Produce, Agricultural Research Organization, The Volcani Center, P.O. Box 6, Bet Dagan 50250, Israel; and sixth author: The Kennedy-Leigh Center for Horticultural Research, Faculty of Agriculture, Food and Environmental Quality Sciences, The Hebrew University of Jerusalem, Rehovot 76100, Israel. Accepted for publication 30 November 2001.

\begin{abstract}
Droby, S., Vinokur, V., Weiss, B., Cohen, L., Daus, A., Goldschmidt, E. E., and Porat, R. 2002. Induction of resistance to Penicillium digitatum in grapefruit by the yeast biocontrol agent Candida oleophila. Phytopathology 92:393-399.

The yeast Candida oleophila, the base of the commercial product Aspire, is recommended for the control of postharvest decay in citrus and pome fruit. Its modes of action include nutrient competition, site exclusion, and direct mycoparasitism. In the present study, we showed that application of Candida oleophila to surface wounds or to intact 'Marsh Seedless' grapefruit elicited systemic resistance against Penicillium digitatum, the main postharvest pathogen of citrus fruit. The induction of pathogen resistance in fruit was already pronounced $24 \mathrm{~h}$ after elicitation;

of pathogen resistance required viable yeast cells at concentrations of $10^{8}$ to $10^{9}$ cells $\mathrm{ml}^{-1}$. Nonviable autoclaved or boiled yeast cells or lower yeast concentrations were ineffective in enhancing fruit disease resistance. Application of Candida oleophila cell suspensions to grapefruit peel tissue increased ethylene biosynthesis, phenylalanine ammonia lyase activity, and phytoalexin accumulation, and increased chitinase and $\beta$ 1,3 -endoglucanase protein levels, indicated by western immunoblotting analysis. Scanning electron microscope observations revealed that spore germination and germ tube growth of Penicillium digitatum were markedly inhibited in wounds made near the yeast-treated sites. Overall, this study provides evidence that induced resistance against postharvest decay of citrus fruit should be considered an important component of the multiple modes of action of the yeast Candida oleophila.
\end{abstract} it was distance, concentration, and time dependent and restricted to the peel tissue closely surrounding the yeast application site. The induction
Additional keywords: citrus, green mold.
Microbial antagonists protect a variety of harvested commodities against a number of postharvest pathogens $(6,9,15,17,18,20,22$, $28,30,31)$. In particular, yeasts that occur naturally on fruits and vegetables have been targeted by many workers as potential antagonists of postharvest diseases because they exhibit a number of traits that enhance their potential for colonizing fruit surfaces (12).

The success of some of these microbial antagonists in laboratory and large-scale studies has stimulated the interest of several companies in the development of biological products for the control of postharvest rots of fruits and vegetables. Currently, four antagonistic microorganisms, two yeasts (Candida oleophila and Cryptococcus albidus) and two strains of the bacterium (Pseudomonas syringae), are commercially available under the trade names Aspire (Ecogen Inc., Langhorn, PA), YieldPlus (Anchor Yeast, Cape Town, South Africa), and BIOSAVE-110 and BIOSAVE-111 (EcoScience, Orlando, FL), respectively.

Although the biocontrol activity of antagonistic bacteria and yeasts has been demonstrated on a variety of commodities, the mode of action of these microbial biocontrol agents has not been fully elucidated. In the case of bacterial antagonists, it has been suggested that their biocontrol activity may be partly associated with the production of antibiotics $(4,19)$.

Antagonistic yeasts have been selected mainly for their capability to rapidly colonize and grow in surface wounds, and subsequently to out compete the pathogen for nutrients and space. Competition for nutrients and space is believed to be the major component of the mode of action of antagonistic yeasts $(8,10$, 15,33). Besides competing for nutrients and space, antagonistic

Corresponding author: S. Droby; E-mail address: samird@ netvision.net.il

Publication no. P-2002-0218-02R

(C) 2002 The American Phytopathological Society yeasts parasitize major postharvest pathogens directly, through strong attachment to their hyphae. This leads to partial disruption of hyphal wall structures $(8,33)$.

Antagonistic yeasts induce several biochemical defense responses in surface wounds. Treatment of wounds in lemons with Pichia guilliermondii enhanced the production of the phytoalexin scoparone (29). Induction of defense responses in apple fruits by the antagonistic yeast Candida saitoana was also reported. Candida saitoana induced chitinase activity and caused deposition of papillae on host cells in apple surface wounds (15). In apple wounds, Aureobasidium pullulans caused transient increases in $\beta$ 1,3-glucanase, chitinase, and peroxidase activities. These increases started $24 \mathrm{~h}$ after treatment and reached maximum levels at 48 and $96 \mathrm{~h}$ after treatment. Wounding also triggered increases in $\beta$-1,3-glucanase, chitinase, and peroxidase activity, but the increases were markedly less than those detected in yeast-treated wounds (18). Fajardo et al. (16) demonstrated that various biologically based elicitors, including Aspire, were capable of inducing resistance to Penicillium digitatum that was inoculated $14 \mathrm{~h}$ after the application of the elicitors to whole, unwounded orange (Citrus sinensis cv. Valencia) fruits. This increased resistance was associated with temporal differential induction of chitinase, $\beta-1,3-$ glucanase, and peroxidase activities.

The objectives of this study were (i) to determine and to characterize the ability of the yeast antagonist Candida oleophila to elicit systemic resistance to Penicillium digitatum in grapefruit flavedo tissue following application of the yeast to either surface wounds or whole intact fruits, and (ii) to determine whether antifungal proteins (chitinase and $\beta$-1,3-glucanase), ethylene, phenylalanine ammonia lyase (PAL), and phytoalexins were induced in flavedo tissue following the application of the yeast cells to either surface wounds or intact fruits. A preliminary report on this work has been published (11). 


\section{MATERIALS AND METHODS}

Plant material. Grapefruits (Citrus paradisi cv. Marsh Seedless) were obtained from a local orchard and were used within 1 to 2 days after harvest (fruit were stored at $11^{\circ} \mathrm{C}$ until used). Prior to use, the fruits were thoroughly washed with tap water and surface sterilized by wiping with technical grade (75\%) ethanol.

Yeast and fungal cultures. The yeast Candida oleophila Montrocher strain 182, the basis of the commercial product Aspire, was initially isolated from the surface of tomato fruits (32). The yeast culture was maintained on silica beads coated with skim milk at $-18^{\circ} \mathrm{C}$, and cultures were grown on nutrient yeast dextrose agar (NYDA) containing $8 \mathrm{~g}$ of nutrient broth, $5 \mathrm{~g}$ of yeast extract, $10 \mathrm{~g}$ of D-glucose, and $20 \mathrm{~g}$ of agar in 1 liter of distilled water. Liquid cultures of the yeast were grown in either 100-ml (for small experiments) or 1,000-ml (for large experiments) Erlenmeyer flasks containing 25 or $250 \mathrm{ml}$ of NYDB, respectively. Following incubation on a rotary shaker at $26^{\circ} \mathrm{C}$ for $48 \mathrm{~h}$, yeast cells were washed once with distilled sterilized water after removal of the growth medium by centrifugation at $3,000 \times g$ for $10 \mathrm{~min}$. Cell pellets were resuspended in distilled sterilized water and brought to the initial concentration of $2 \times 10^{9}$ to $5 \times 10^{9}$ cells per $\mathrm{ml}$. The final cell concentration was adjusted as needed for the various experiments.

Cultures of Penicillium digitatum (Pers. Fr.) Sacc. were isolated from decayed citrus fruit, stored on potato dextrose agar (PDA, Difco Laboratories, Detroit) slants at $4^{\circ} \mathrm{C}$, and grown on PDA plates for 1 week at $25^{\circ} \mathrm{C}$. Spore suspensions were prepared by removing the spores from the sporulating edges of a 2- to 3-weekold culture with a bacteriological loop and suspending them in sterile distilled water. The spore concentration was adjusted to $5 \times$ $10^{4}$ spores $\mathrm{ml}^{-1}$ with a hemacytometer.

Effects of Candida oleophila on the induction of resistance against Penicillium digitatum. Fruits were gently wounded (1 to $2 \mathrm{~mm}$ deep) with a dissecting needle at three different sites around their blossom end, and a $20-\mu \mathrm{l}$ aliquot of aqueous cell suspension of Candida oleophila at the desired concentration was pipetted into each wound site. Wounds treated with the same amount of distilled sterilized water served as controls. After $24 \mathrm{~h}$ incubation at $20^{\circ} \mathrm{C}$, fresh wounds were made at a distance of $1 \mathrm{~cm}$ from the yeast-treated wounds and the control wounds, and were inoculated with $20 \mu \mathrm{l}$ of spore suspension of Penicillium digitatum $(5 \times$ $10^{4}$ spores per $\left.\mathrm{ml}\right)$. The fruits were then incubated at $20^{\circ} \mathrm{C}$ in

TABLE 1. Effects of the distance of the infected site from the Candida oleophila-treated wounds, the time of fruit inoculation after yeast application, and yeast cell concentrations on the resistance of grapefruit against Penicillium digitatum

\begin{tabular}{lcc}
\hline Treatment & Decay $(\% \text { of control })^{\mathrm{x}}$ & ${\text { Rot diameter }(\mathrm{mm})^{\mathrm{y}}}$ \\
\hline Distance $(\mathrm{cm})$ & $32 \mathrm{c}^{\mathrm{z}}$ & $24 \mathrm{~b}$ \\
1 & $49 \mathrm{~b}$ & $29 \mathrm{~b}$ \\
2 & $60 \mathrm{~b}$ & $32 \mathrm{ab}$ \\
4 & $85 \mathrm{a}$ & $44 \mathrm{a}$ \\
8 & & \\
Time of inoculation (h) & $82 \mathrm{a}$ & $43 \mathrm{a}$ \\
0 & $40 \mathrm{~b}$ & $37 \mathrm{ab}$ \\
24 & $40 \mathrm{~b}$ & $31 \mathrm{~b}$ \\
48 & $37 \mathrm{~b}$ & $27 \mathrm{~b}$ \\
72 & & \\
Concentration (cells per ml) & $98 \mathrm{a}$ & $48 \mathrm{a}$ \\
$10^{6}$ & $90 \mathrm{a}$ & $43 \mathrm{ab}$ \\
$10^{7}$ & $55 \mathrm{~b}$ & $36 \mathrm{~b}$ \\
$10^{8}$ & $41 \mathrm{c}$ & $31 \mathrm{~b}$ \\
$10^{9}$ &
\end{tabular}

${ }^{x}$ Average percent infection in the control is $88 \%$.

y Rot diameter in the control ranged from 45 to $50 \mathrm{~mm}$.

${ }^{\mathrm{z}}$ Values followed by different letters are significantly different at $P<0.05$ according to a Student-Newman-Keuls one-way analysis of variance test on ranks. plastic trays under humid conditions, and the percentages of infected wounds were determined 4 days after inoculation. Each treatment consisted of three replications of 12 fruits each (total of 108 wounds per treatment). Each experiment was repeated at least three times with similar results.

To assess the effects of various concentrations of Candida oleophila in eliciting resistance to Penicillium digitatum, similar experiments were performed with yeast cell concentrations of $10^{9}$, $10^{8}, 10^{7}$, and $10^{6}$ cells per ml. The development of resistance at various distances from the elicited wounds was evaluated by inoculating the fruits at $1,2,4$, and $8 \mathrm{~cm}$ from the yeast-treated site. The ability of Candida oleophila to elicit resistance in whole intact fruits was tested by dipping the fruits in the yeast cell suspension $\left(10^{8}\right.$ cells per ml) for $20 \mathrm{~s}$, allowing them to air dry, and keeping them for $24 \mathrm{~h}$ at $20^{\circ} \mathrm{C}$. The fruits were then surfacesterilized by wiping extensively with pure ethanol to remove yeast cells from the surface and were wound-inoculated at three sites as described previously.

The effect of nonviable Candida oleophila cells, as well as Baker's yeast, on induction of resistance in grapefruit was evaluated. Candida oleophila culture was harvested as previously described, and the concentration was adjusted to $10^{9}$ cells per ml. The cell suspension was divided to three portions: (i) boiled for $30 \mathrm{~min}$, (ii) autoclaved for $20 \mathrm{~min}$, and (iii) untreated control. Saccharomyces cerevisiae (Baker's yeast) type II (Sigma Chemical, St. Louis) was grown in NYDB for $48 \mathrm{~h}$ and harvested and concentration was adjusted to $10^{9}$ cells per $\mathrm{ml}$ as described for Candida oleophila.

Ethylene determination. Production of ethylene was determined in grapefruit peel disks treated with Candida oleophila cells at a concentration of $10^{8}$ cell per $\mathrm{ml}$. Peel disks $(13 \mathrm{~mm}$ in diameter and 2 to $3 \mathrm{~mm}$ thick) were cut from the flavedo (rind) part of the fruit peel with a cork borer and immersed for $30 \mathrm{~s}$ in the aqueous yeast cell suspension. The disks were then placed in 50-ml Erlenmeyer flasks on moist filter paper. Each treatment consisted of five replicates of 50-ml Erlenmeyer flasks, each containing five peel disks. The rate of ethylene production was determined by analyzing the concentration of ethylene accumulated in the atmosphere of the flasks above the fruit tissue during a 1-h sealed period, as described previously (5). Two-milliliter gas samples were withdrawn from the flask with a hypodermic syringe, and ethylene concentrations in the samples were determined by gas chromatography in a mesh column (Hayesep T. 100/120; Alltech Associates, Deerfield, IL).

PAL activity. PAL activity was determined according to Lisker et al. (24). Briefly, $10 \mathrm{~g}$ of flavedo was removed and homogenized in $100 \mathrm{ml}$ of acetone at $-5^{\circ} \mathrm{C}$, and the homogenate was filtered

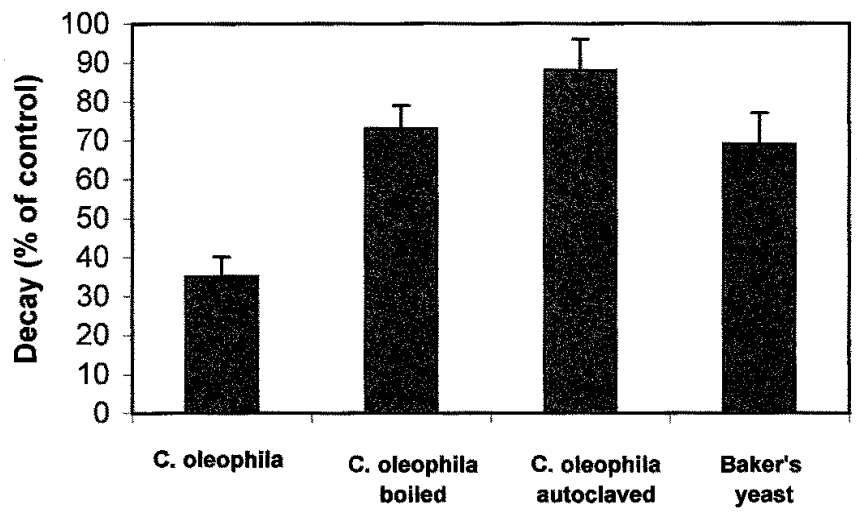

Fig. 1. Effects of viable and nonviable Candida oleophila cells on the resistance of grapefruit against Penicillium digitatum. The percentages of wounds that exhibited disease symptoms were measured after 4 days of incubation at $20^{\circ} \mathrm{C}$. Thirty-six fruits with three wounds each were used per treatment (total of 108 wounds). Bars indicate standard error of the mean. 
through Whatman No. 1 filter paper. This step was repeated three times, and the acetone powder was then air dried for $3 \mathrm{~h}$ and stored at $-15^{\circ} \mathrm{C}$ pending use. For the PAL assay, $500 \mathrm{mg}$ of the acetone powder was added to $10 \mathrm{ml}$ of cold $0.1 \mathrm{M}$ borate buffer,

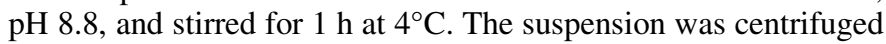
for $10 \mathrm{~min}$ at $12,000 \times \mathrm{g}$, and the supernatant was dialyzed against $0.2 \mathrm{M}$ borate buffer, $\mathrm{pH} 8.8$, for $48 \mathrm{~h}$ at $4^{\circ} \mathrm{C}$. PAL activity was determined by incubating $1.5 \mathrm{ml}$ of enzyme preparation, $2.5 \mathrm{ml}$ of $0.1 \mathrm{M}$ borate buffer, $\mathrm{pH} 8.8$, and $1 \mathrm{ml}$ of $0.05 \mathrm{M}$ L-phenylalanine as a substrate for $1 \mathrm{~h}$ at $40^{\circ} \mathrm{C}$. The reaction was stopped by adding $0.5 \mathrm{ml}$ of $5 \mathrm{~N} \mathrm{HCl}$ and $7 \mathrm{ml}$ of diethyl ether. The mixture was then centrifuged at $12,000 \times g$ for $5 \mathrm{~min}$, and $3.5 \mathrm{ml}$ of the clear ether supernatant was taken for spectrophotometric measurements of cinnamic acid at $\lambda=269$. The results were expressed as micromole cinnamic acid per gram dry weight per hour.

Extraction of phytoalexins. Phytoalexins were extracted according to Afek and Sztejnberg (1). Peel strips $(2 \times 8 \mathrm{~cm}$, 4 to $6 \mathrm{~mm}$ thick, total of $50 \mathrm{~g}$ per sample) were removed from intact fruits with a sharp scalpel and dipped in yeast cell suspension $\left(10^{8}\right.$ cells per $\left.\mathrm{ml}\right)$ or water (control). Treated peel samples were kept at room temperature and extracted at various times after treatment. Phytoalexins extraction was made by incubating each sample in $100 \mathrm{ml}$ of distilled water for $2 \mathrm{~h}$ at $65^{\circ} \mathrm{C}$. Peel tissues were removed by filtration through four layers of cheesecloth and the filtrate was evaporated to dryness with an evaporator (Rotoevaporator-R; Rotovac, Buchi, Switzerland). The dry concentrate was dissolved in $20 \mathrm{ml}$ of ethyl acetate and incubated for $48 \mathrm{~h}$ at $4^{\circ} \mathrm{C}$, centrifuged at $3,000 \times g$ for $5 \mathrm{~min}$, and the supernatant was concentrated again by evaporation. This time the pellet was dissolved in $5 \mathrm{ml}$ of ethyl acetate and analyzed by thin-layer chromatography (TLC) (0.5 mm, Kieselgel 60 GF 254, Merck, Germany) developed using toluene/EtOAc (1:1, vol/vol). Samples of umbelliferone, scoparone, and scopoletin (provided by V. Rodov, Bet Dagan, Israel) were used as standards. The developed chromatograms were dried and illuminated under UV light $(350 \mathrm{~nm})$. The intensity of bands in the chromatograms were densiometrically analyzed using the Liscap image capture and Tina image master 1D/2D software (Pharmacia Biotech Inc., Piscataway, NJ).

Protein extraction and immunoblotting analysis. Protein extraction and immunoblotting was performed according to Lers et al. (23). Flavedo tissue ( $1 \mathrm{~g})$ was homogenized with a mortar and pestle in $2 \mathrm{ml}$ of ice-cold $20 \mathrm{mM}$ Tris- $\mathrm{HCl}, \mathrm{pH} \mathrm{7.5}$, and centrifuged at $10,000 \times g$ for $20 \mathrm{~min}$ to remove cell debris. The supernatant was filtered through four layers of Miracloth, and the soluble protein concentration was determined according to Bradford (3). Ten micrograms of proteins were separated by $12 \%$ sodium dodecyl sulfate-polyacrylamide gel electrophoresis with a mini PROTEIN II apparatus (Bio-Rad, Hercule, CA) and transferred to nitrocellulose membranes with a Bio-Rad Mini Trans-Blot electrophoresis unit. Immunodetection was performed with citrus chitinase and $\beta-1,3$-endoglucanase antibodies (provided by R. E. McDonald, Orlando, FL) according to McCollum et al. (25). The primary antibody reacting bands were visualized by means of commercial secondary antibodies conjugated to alkaline phosphatase (Bio-Rad) according to the manufacturer's instructions. Each experiment was repeated twice with different protein extractions.

Scanning electron microscope observations. Peel disks with inoculated wounds were excised from water control or from Candida oleophila-treated fruits and immediately frozen by placing them on a copper block cooled with liquid nitrogen. The frozen samples were further dried by sublimation in a high-vacuum device as described by Newbury et al. (26). The samples were viewed with a scanning electron microscope (SEM) (GSMT300A; JEOL, Tokyo) at 10 and $15 \mathrm{kV}, 0$ and 30 degree tilt, and $10 \mathrm{~mm}$ working distance. Samples from four fruits of each treatment were used.

Statistical analysis. Student-Newman-Keuls one way analysis of variance test on ranks was performed to determine the effect of distance from the Candida oleophila-treated wounds, time of fruit inoculation, and yeast cell concentration on induction of resistance. Decay was calculated as percentage of infected wounds in each replicate (12 fruits with a total of 36 wounds). Rot development was recorded in each infected wound and expressed as rot diameter in millimeters.

\section{RESULTS}

Induction of resistance to Penicillium digitatum. Application of Candida oleophila to surface wounds induced resistance to Penicillium digitatum in peel tissue in the vicinity of the yeasttreated sites (Table 1). The level of resistance depended on (i) distance of the Penicillium digitatum-inoculated wounds from the yeast-treated sites, (ii) time of wound-inoculation, and (iii) concentration of the yeast cell suspension used. The most pronounced reduction in decay incidence was in Penicillium digitatuminoculated wounds at a distance of $1 \mathrm{~cm}$ from the Candida oleophila-treated sites (Table 1). At this distance, the percentage of wounds that developed decay was only $32 \%$ of that in the controls. The level of protection decreased as the distance of inoculated wounds from the yeast-treated sites increased. The percentages of decay developed in wounds at 2,4 , and $8 \mathrm{~cm}$ from the yeast-treated wound sites were 50,60 , and $85 \%$, respectively, of those in the controls (Table 1).

The development of resistance in grapefruit peel tissue near the Candida oleophila-treated sites was monitored by inoculating fresh wounds at various times after the Candida oleophila application. As presented in Table 1, results indicated that the percentage of infection was highest ( $82 \%$ of the control) in fruits that were wounded and inoculated immediately after the yeast application. The infection percentage decreased to approximately $40 \%$ of that in the control when inoculation was performed 24,48 , and $72 \mathrm{~h}$ after the yeast application.

The average rot diameter of decay developed in infected wounds nearby the Candida oleophila-treated wounds was reduced by approximately 14 to $37 \%$ of that measured in the control (Table 1).

The induction of resistance in peel tissue was also dependent on the concentration of Candida oleophila applied in surface wounds. The most effective yeast concentrations in inducing fruit resistance against Penicillium digitatum were $10^{8}$ and $10^{9}$ cells per $\mathrm{ml}$; lower yeast concentrations $\left(10^{7}\right.$ and $10^{6}$ cells $\left./ \mathrm{ml}\right)$ were ineffective (Table 1).

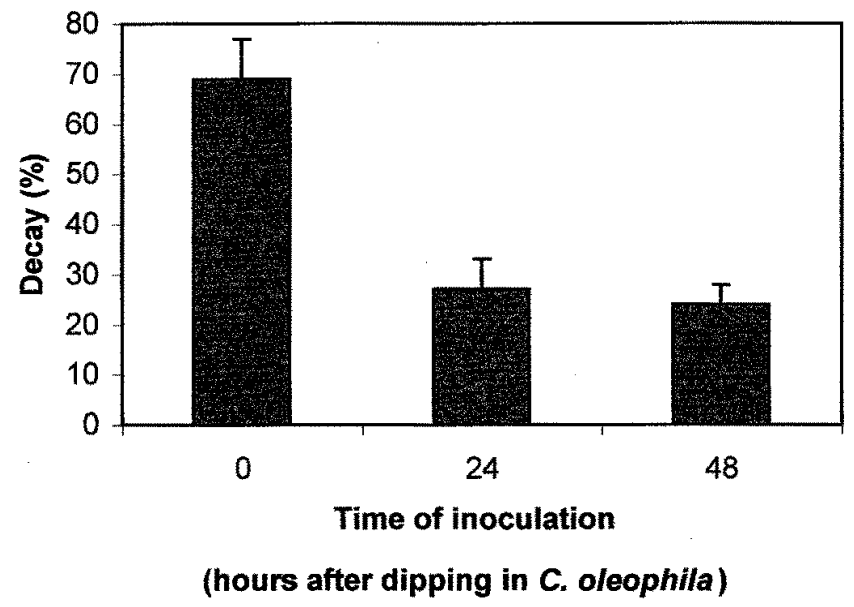

Fig. 2. Effects of dipping nonwounded grapefruit in a Candida oleophila cell suspension on their resistance against Penicillium digitatum. The percentages of wounds that exhibited disease symptoms were measured after 4 days of incubation at $20^{\circ} \mathrm{C}$. Thirty-six fruits with three wounds each were used per treatment (total of 108 wounds). Bars indicate standard error of the mean. 
Only viable Candida oleophila cells applied to surface wounds were capable of inducing maximum resistance to Penicillium digitatum; autoclaved or boiled cells were much less effective (Fig. 1). Baker's yeast cells at similar concentration had only a limited effect on the induction of resistance compared with the effect of Candida oleophila (Fig. 1).

Candida oleophila was capable of inducing systemic resistance in fruit, not only through application to surface wounds, but also by interacting with the intact fruit surface. Dipping nonwounded grapefruits in a Candida oleophila cell suspension 24 or $48 \mathrm{~h}$ before inoculation induced significant pathogen resistance in the fruit and reduced the percentage of decayed wounds by 61 and $65 \%$, respectively, compared with control fruits dipped in water alone (Fig. 2).

Enhancement of ethylene, PAL, and phytoalexins production in grapefruit peel tissue. Ethylene evolution in grapefruit peel disks treated with Candida oleophila cell suspension is shown in Figure 3. Ethylene evolution measured immediately after the treatment was not detectable. After $24 \mathrm{~h}$, the yeast-treated disks showed an approximate 3.5-fold increase in ethylene production compared with the water-treated control disks. Ethylene production continued to increase after $48 \mathrm{~h}$ of incubation and was approximately three times as high as that recorded in control disks.

PAL activity in Candida oleophila-treated peel tissue was measured at various times after yeast treatment. PAL activity in the yeast-treated tissue increased within $24 \mathrm{~h}$ after treatment and at $48 \mathrm{~h}$ was significantly higher than that measured in controls. Activity continued to increase in the yeast-treated peel tissue and after $72 \mathrm{~h}$ of incubation its level was almost twice that of controls (Fig. 4).

The accumulated levels of the phytoalexins umbelliferone, scoparone, and scopoletin in Candida oleophila-challenged grapefruit peel tissue and in water-treated controls were determined at various times after yeast treatment. TLC analysis of the peel extracts showed increased amounts of the three phytoalexins in the yeast-treated peel tissue after 24,48 , and $72 \mathrm{~h}$ of incubation compared with those in the control treatment, with the accumulation of scopoletin being the most pronounced. Analysis of band intensity after $72 \mathrm{~h}$ of incubation showed 6.3-, 3.0-, and 3.2-fold increase in scopoletin, scoparone, and umbelliferone, respectively, in the yeast-treated tissue relative to the control. In addition, the TLC analysis revealed that substances other than the above three phytoalexins were enhanced in the yeast-treated tissue compared with the controls (Fig. 5).

Induction of chitinase and $\beta$-1,3-endoglucanase. Application of Candida oleophila cell suspensions to either peel disks or the intact whole fruit induced the accumulation of chitinase and $\beta$ -

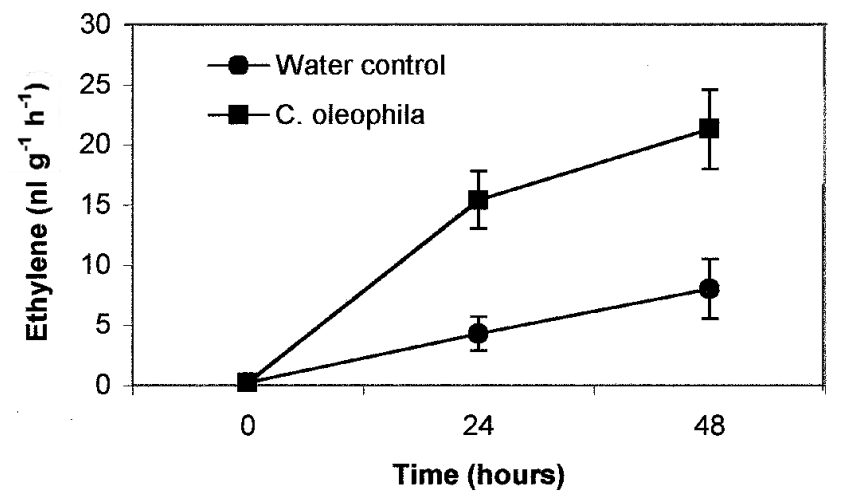

Fig. 3. Effects of Candida oleophila treatment on ethylene production in grapefruit peel disks. Each data point represents an average of results obtained from three experiments. Bars indicate standard error of the mean. 1,3-endoglucanase proteins (Fig. 6). In both cases, treatment with Candida oleophila markedly induced chitinase protein accumulation (as evidenced by the band stain intensity), but had a much smaller effect on the accumulation of $\beta$-1,3-endoglucanase (Fig. $6 \mathrm{~A}$ and $\mathrm{B})$. After $48 \mathrm{~h}$, a moderate increase in chitinase was observed in water-treated control peel disks. This increase was probably related to the wounding of the tissue because it was not evident in peel tissue obtained from unwounded fruit (Fig. 6A). Dipping peel disks in a Candida oleophila cell suspension markedly increased the accumulation of $24-\mathrm{kD}$ chitinase compared with those in control disks dipped in water (Fig. 6A). Intact fruits dipped in Candida oleophila already showed increased accumulation of the same $24-\mathrm{kD}$ chitinase after 1 day of incubation, and this increase continued and intensified over a period of up to 7 days (Fig. 6A).

The effect of Candida oleophila treatment on the accumulation of $\beta$-1,3-endoglucanase in peel disks and intact fruit was much less pronounced than its effect on chitinase. In peel disks, an accumulation of a $39-\mathrm{kD} \beta-1,3$-endoglucanase above that found in control fruits was observed only after $48 \mathrm{~h}$ of incubation (Fig. 6B). In intact fruits, a slight induction of 39-kD $\beta$-1,3-endoglucanase protein accumulation was observed after $24 \mathrm{~h}$, and it continued to increase after 5 and 7 days of incubation.

SEM observations. Germination and growth of Penicillium digitatum in surface wounds made near $1 \mathrm{~cm}$ from Candida oleophila-challenged wound sites were observed with a scanning electron microscope after 24 and $48 \mathrm{~h}$ of incubation (Fig. 7). Observations made after $24 \mathrm{~h}$ revealed complete inhibition of spore germination in Penicillium digitatum-inoculated wounds adjacent to the yeast-treated wounds (Fig. 7B), in contrast to normal germination and germ tube growth in similar wounds near water-treated control wounds (Fig. 7A). At $48 \mathrm{~h}$, restricted hyphal growth and spore germination of Penicillium digitatum was observed in the inoculated wounds near the yeast-treated ones (Fig. 7D), whereas massive hyphal growth was evident in those near the water-treated wound sites (Fig. 7C). In most cases, abnormal growth of Penicillium digitatum germ tubes, collapsed mycelia, and swelling of spores were observed in peel tissue wounds near the yeastchallenged sites (Fig. 7F and $\mathrm{H}$ ) and normal spore and mycelial shapes were evident in the control treatment (Fig. 7E and G).

\section{DISCUSSION}

Results of the present study provide evidence that cells of the yeast antagonist Candida oleophila applied to surface wounds are capable of eliciting resistance to Penicillium digitatum in grapefruit flavedo tissue at some distance from the challenged sites. In addition, application of the yeast to whole unwounded fruits was

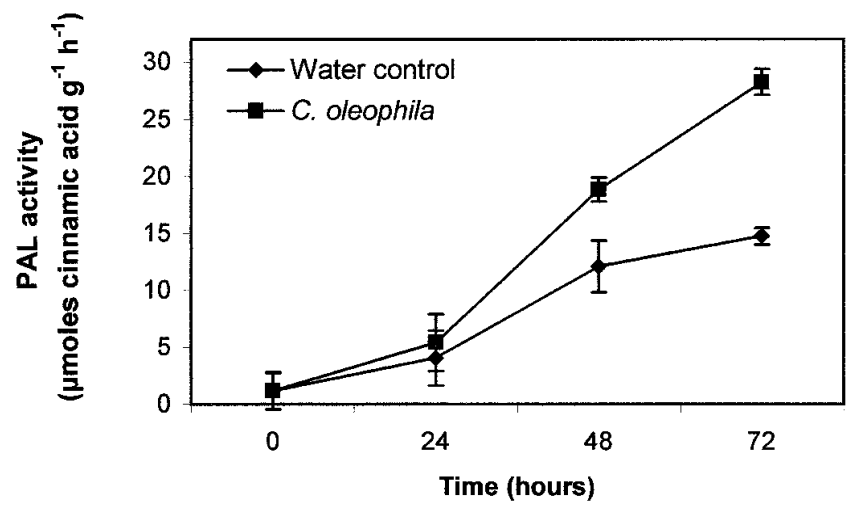

Fig. 4. Effects of Candida oleophila treatment on phenylalanine ammonia lyase (PAL) activity in grapefruit peel tissue. Each data point represents an average of results obtained from three experiments. Bars indicate standard error of the mean. 
found to induce resistance to Penicillium digitatum inoculated $24 \mathrm{~h}$ later. In the first case (elicitation through surface wounds), maximum resistance was evident in close proximity $(1 \mathrm{~cm})$ to the yeast-challenged wound (Table 1). Development of resistance was time and yeast concentration dependent and was most significantly with viable yeast cells (Table 1; Fig. 1). The fact that only viable yeast cells were able to elicit a significant resistance response and the gradual development of the resistance suggests the possible involvement of active recognition processes between yeast cells and fruit tissue and active secretion of elicitors by the
Candida oleophila cells. This hypothesis, however, still needs to be supported by further experimental data.

Most research on biological control of postharvest diseases has concentrated mainly on microorganisms that are antagonistic to wound pathogens. Typically, infection of wounds by spores of the pathogen is very rapid (often within $24 \mathrm{~h}$ ). Thus, rapid colonization and growth of an antagonist in the wound site has been identified as a key requisite of a successful antagonist. Along with rapid growth in the wound site, microbial biocontrol agents interact with wounded tissue and induce various biochemical changes

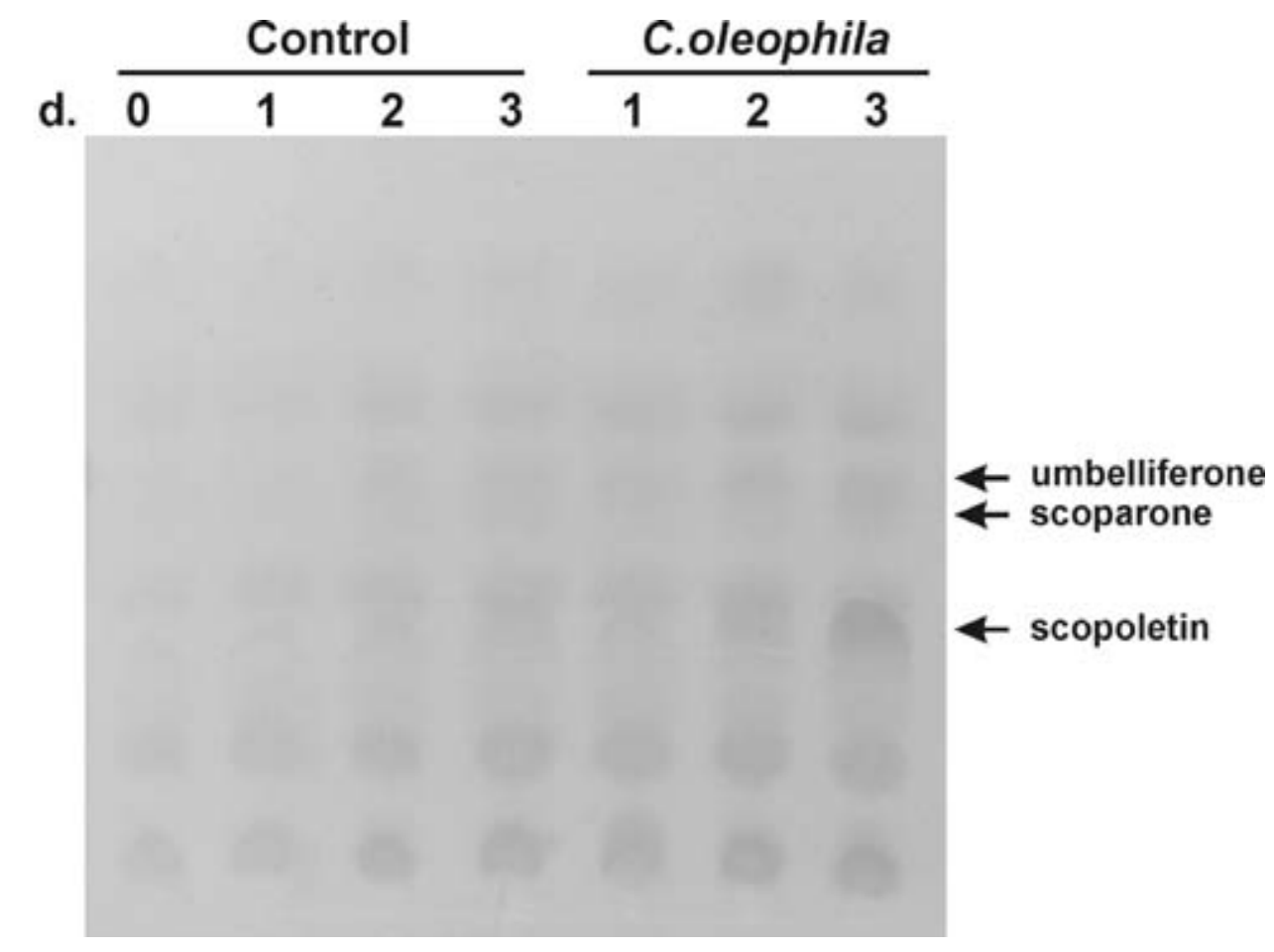

Fig. 5. Thin-layer chromatography analysis of the effects of Candida oleophila treatment on the accumulation of phytoalexins in grapefruit peel tissue. The arrows at the right indicate the purified scopoletin, scoparone, and umbelliferone phytoalexin standards ( $\mathrm{d}=$ days).

\section{Peel disks}

A. Chitinase
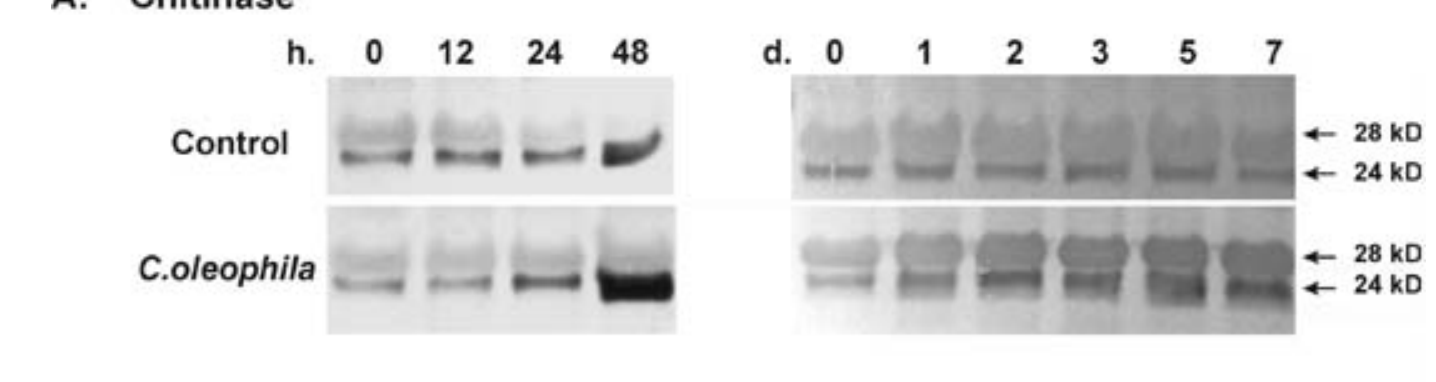

B. Glucanase

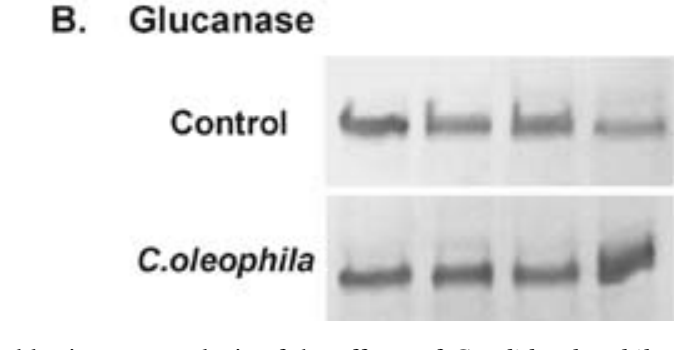

\section{Intact fruit}

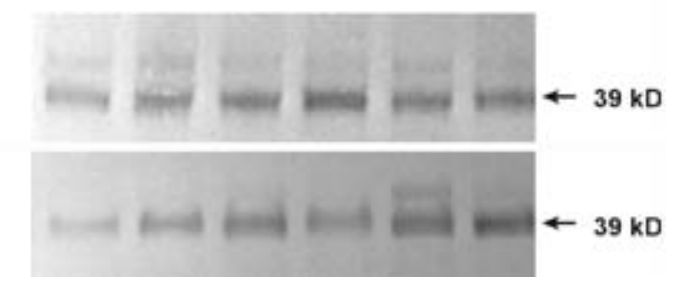

Fig. 6. Western blot immunoanalysis of the effects of Candida oleophila on the accumulation of chitinase and $\beta$-1,3-endoglucanase proteins in grapefruit peel tissue. The arrows and values at the right indicate the approximate molecular mass of the grapefruit cross-reacting polypeptides $(\mathrm{h}=\mathrm{hours} ; \mathrm{d}=\mathrm{days})$. 
in wounds such as enhancement of chitinase, $\beta$-1,3-glucanase, and peroxidase activities, and formation of structural barriers and accumulation of phytoalexins $(14,29)$.

The present study has demonstrated that various resistance responses were activated in the vicinity of wounds and in whole intact fruits following treatment with Candida oleophila. These responses were highest close to the site of elicitation, and resistance to Penicillium digitatum decreased as the distance of the inoculation from the challenged wound increased. From the practical standpoint, activation of resistance mechanisms at points beyond the wound site is important for protection against future wound infections and also for the restriction of fungal growth and sporulation in the case of decay developing from yeast-treated or untreated surface wounds. Indeed, in most of our experiments, we observed that the expansion of decay that developed from yeasttreated wounds was much slower than that on control untreated fruits. In addition, sporulation on this decayed tissue was low (data not shown).
Resistance responses that were activated included increased ethylene production, PAL activity, phytoalexin biosynthesis, and the apparent accumulation of chitinase and $\beta$-1,3-glucanse proteins (Figs. 3 to 7). Enhancement of ethylene production and PAL activity in citrus peel tissue following application of the yeast antagonist Pichia guilliermondii was reported previously (8), and it was assumed that ethylene was directly involved in activation of resistance mechanisms because exposure of either peel disks or whole fruits to exogenous ethylene induced resistance to Penicillium digitatum infections (8). Ethylene also induces various pathogen defense mechanisms in other plant systems; these mechanisms included PAL activity and hydrolytic enzymes $(2,7,13)$. However, our preliminary work indicated that treatment of grapefruits with 1-methylcyclopropene, a gaseous ethylene-action inhibitor (27), either before or after application of Candida oleophila, had no effect on the induction of fruit resistance against Penicillium digitatum (data not shown). This result indicates that the increase in ethylene biosynthesis is possibly another factor

\section{Control}
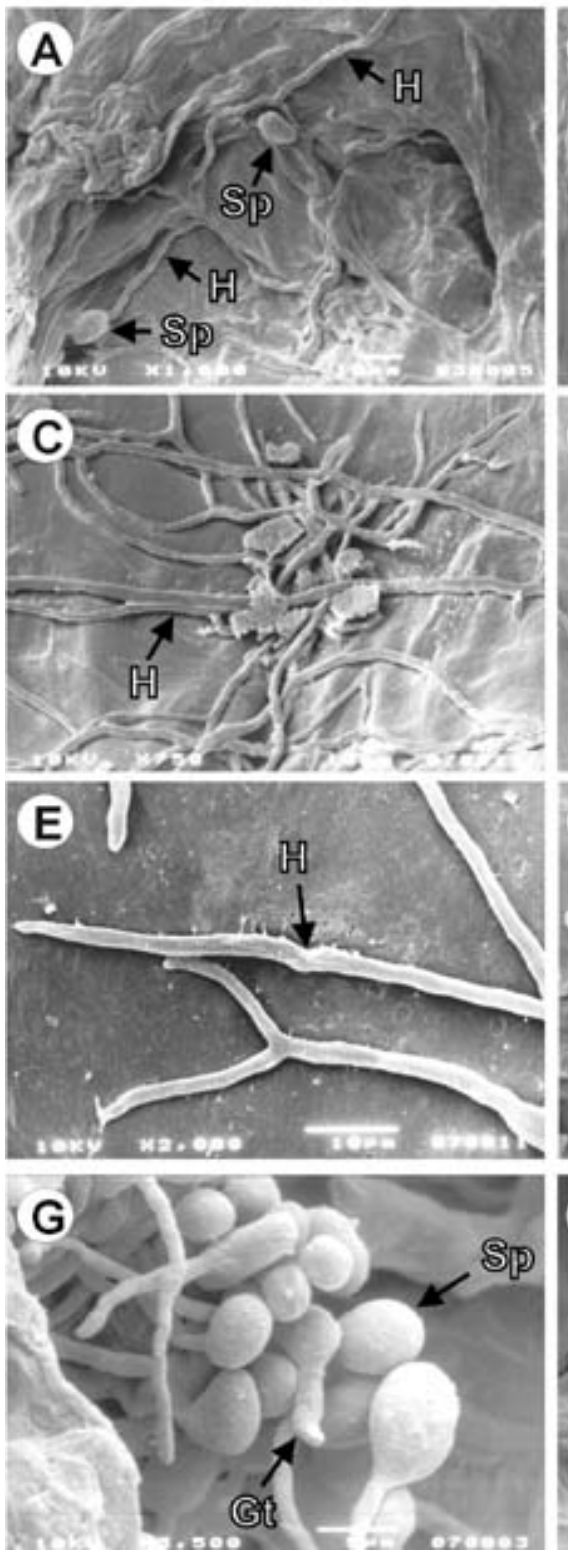

\section{C.oleophila}
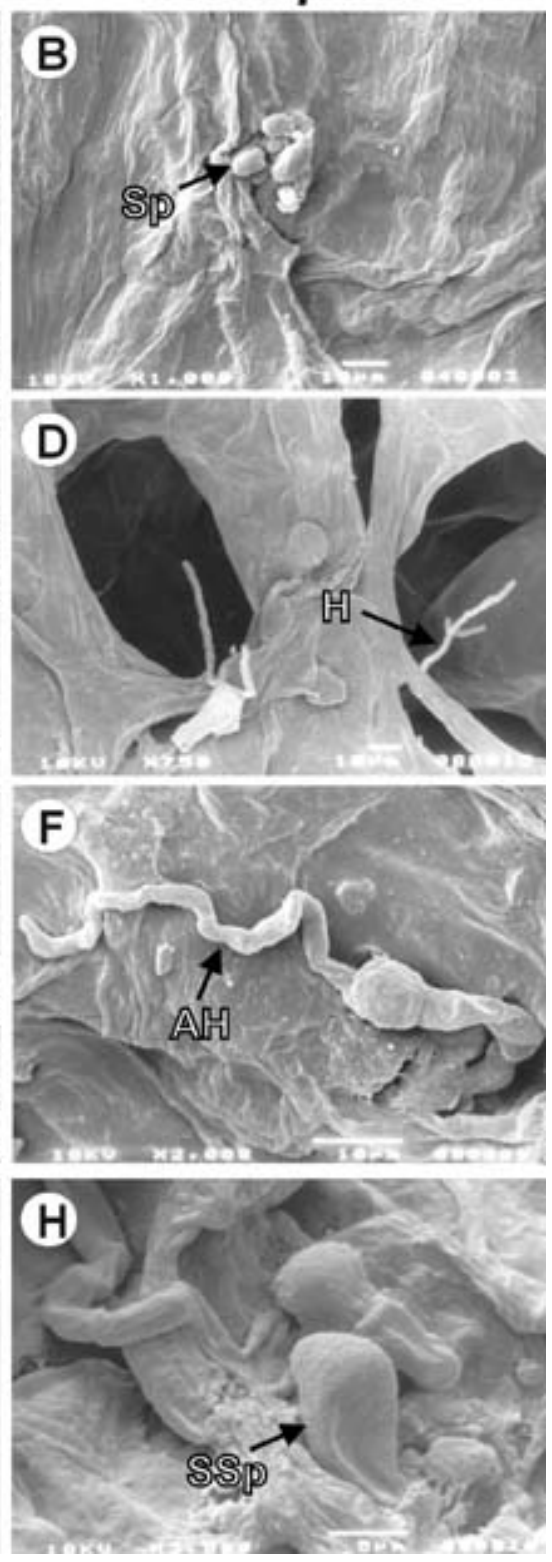

Fig. 7. Scanning electron microscope images of Penicillium digitatum spores and germ tubes in artificially inoculated wounds made near water-treated (controls) or Candida oleophila-treated wound sites. A and B, Wound surfaces after $24 \mathrm{~h}$; magnification $\times 1,000$. C and D, Wound surfaces after $48 \mathrm{~h}$; magnification $\times 750$. E and F, Enlargement of Penicillium digitatum germ tubes after $48 \mathrm{~h}$; magnification $\times 2,000$. G and $\mathbf{H}$, Enlargement of Penicillium digitatum spores after $48 \mathrm{~h}$; magnification $\times 3,500 . \mathrm{Sp}=$ spore; $\mathrm{H}=$ hyphae; $\mathrm{AH}=$ abnormal hyphae; $\mathrm{Gt}=$ germ tube; and $\mathrm{SSp}=$ swollen spore. 
among the complex fruit responses to the yeast cells, and that its role in the induced resistance response has yet to be determined.

The ability of Candida oleophila to increase PAL activity and accumulation of the phytoalexins scoparone, scopoletin, umbelliferone, and of other phenolic substances in grapefruit peel strips provides evidence of the enhanced production of secondary metabolites that are needed to inhibit pathogen infection, directly or indirectly. The involvement of phytoalexins in plant resistance to fungal attack has been extensively studied (21).

Induction of chitinase increased markedly in both peel disks and intact fruits following treatment with the antagonist cells. On the other hand, accumulation of $\beta$-1,3-glucanase proteins was much less pronounced. This result is in full agreement with our previous findings that exposure of grapefruit to UV light markedly enhanced the accumulation of chitinase but had a much smaller effect on $\beta$-1,3-glucanase. McCollum et al. (25) reported that weak induction of enzyme activity could be associated with the developmental stage of the plant. Chitinase activity was highest at the immature stage (green fruit) of fruit development, when glucanase activity was at its lowest. In the present study, however, mature fruits were used. The question of whether chitinases and glucanases affect infection and development of Penicillium digitatum in grapefruit remains to be further investigated.

The resistance that developed in grapefruit peel tissue adjacent to yeast-challenged wounds was visually demonstrated by means of SEM examination of inoculated wounds. Spore germination and hyphal growth were markedly restricted and, in many cases, the typical responses (swelling and shriveling) of fungal structures to the presence of inhibitory compounds were evident (Fig. 7). The presence of bioactive substances is likely to be responsible for the inhibition and subsequent suppression of infection that was observed in the present study.

Although the relative importance of the role of induced disease resistance in the mode of action of the yeast biocontrol agent $\mathrm{Can}$ dida oleophila remains to be determined, the observed accumulation of chitinase, $\beta$-1,3-glucanase, PAL, and phytoalexins in yeasttreated tissues suggests that these biochemical defense responses might be involved in the biocontrol activity of the antagonist. Although biological control is almost certainly the culmination of the effects of many factors, it is quite possible that yeast-mediated defense reactions play a supporting role in restricting the spread of fungal infection in wound sites as well as in intact tissue.

\section{LITERATURE CITED}

1. Afek, U., and Sztejnberg, A. 1993. Temperature and gamma irradiation effects on scoparone, a citrus phytoalexin conferring resistance to Phytophthora citrophthora. Phytopathology 83:753-758.

2. Boller, T. 1988. Ethylene and the regulation of antifungal hydrolases in plants. Oxf. Surv. Plant Mol. Cell Biol. 5:145-174.

3. Bradford, M. M. 1996. A rapid and sensitive method for the quantification of microgram quantities of protein utilizing the principle of protein dye binding. Anal. Biochem. 72:248-254.

4. Bull, C. T., Stack, J. P., and Smilanick, J. L. 1997. Pseudomonas syringae strains ESC-10 and ESC-11 survive in wounds on citrus and control green and blue molds of citrus. Biol. Control 8:81-88.

5. Chalutz, E., Liberman, M., and Sisler, H. D. 1977. Methionine-induced ethylene production by Penicillium digitatum. Plant Physiol. 60:402-404.

6. Chand-Goyal, T., and Spots, R. A. 1996. Control of postharvest pear diseases using natural saprophytic yeast colonists and their combination with low doses of thiabendazole. Postharv. Biol. Technol. 7:51-64.

7. Chappell, J., Hahlbrock, K., and Boller, T. 1984. Rapid induction of ethylene biosynthesis in cultured parsley cells by fungal elicitor and its relationship to the induction of phenylalanine ammonia-lyase. Planta $161: 475-480$.

8. Droby, S., and Chalutz, E. 1994. Mode of action of biocontrol agents for postharvest diseases. Pages 63-75 in: Biological Control of Postharvest Diseases of Fruits and Vegetables-Theory and Practice. C. L. Wilson and M. E. Wisniewski, eds. CRC Press, Boca Raton, FL.

9. Droby, S., Chalutz, E., and Wilson, C. L. 1991. Antagonistic micro- organisms as biological control agents of postharvest diseases of fruits and vegetables. Postharv. News Inf. 2:169-173.

10. Droby, S., Chalutz, E., Wilson, C. L., and Wisniewski, M. E. 1989. Characterization of the biocontrol activity of Debaryomyces hansenii in the control of Penicillium digitatum on grapefruit. Can. J. Microbiol. 35:794-800.

11. Droby, S., Porat, R., Vinocur, V., Cohen, L., Weiss, B., and Daus, A. 2000. Induction of resistance to postharvest decay of citrus fruit by the yeast biocontrol agent Candida oleophila. (Abstr.) Phytopathology 90(suppl.):S20.

12. Droby, S., Wilson, C. L., Wisniewski, M., and El Ghaouth, A. 2000. Biologically based technology for the control of postharvest diseases of fruits and vegetables. Pages 187-205 in: Microbial Food Contamination. C. L. Wilson and S. Droby, eds. CRC Press, Boca Raton, FL.

13. Ecker, J. R., and Davis, R. W. 1987. Plant defense genes are regulated by ethylene. Proc. Natl. Acad. Sci. USA 84:5202-5206.

14. El Ghaouth, A., Arul, J., Wilson, C., and Benhamou, N. 1994. Ultrastructural and cytochemical aspects of the effect of chitosan on decay of bell pepper fruit. Physiol. Mol. Plant Pathol. 44:417-432.

15. El-Ghaouth, A., Wilson, C. L., and Wisniewski, M. 1998. Ultrastructural and cytochemical aspects of the biological control of Botrytis cinerea by Candida saitoana in apple fruit. Phytopathology 88:282-291.

16. Fajardo, J. E., McCollum, T. G., McDonald, R. E., and Mayer, R. T. 1998. Differential induction of proteins in orange flavedo by biologically based elicitors and challenged by Penicillium digitatum Sacc. Biol. Control 13:143-151.

17. Gullino, M. L., Aloi, C., Palitto, M., Benzi, D., and Garibaldi, A. 1991. Attempts at biocontrol of postharvest diseases of apple. Meded. Fac. Landbouwwet. Rijksuniv. Gent 56:195.

18. Ippolito, A., El Ghaouth, A., Wilson, C. L., and Wisniewski, M. 2000. Control of postharvest decay of apple fruit by Aureobasidium pullulans and induction of defense responses. Postharv. Biol. Technol. 19:265-272.

19. Janisiewicz, W., Yourman, L., Roitman, J., and Mahoney, N. 1991. Postharvest control of blue mold and gray mold of apples and pears by dip treatment with pyrrolnitrin, a metabolite of Pseudomonas cepacia. Plant Dis. 75:490-494.

20. Janisiewicz, W. J., Peterson, D. L., and Bors, R. 1994. Control of storage decay of apples with Sporobolomyces roseus. Plant Dis. 78:466-470.

21. Kuc, J. 1990. Immunization for the control of plant disease. Pages 355373 in: Biological Control of Soil-Borne Plant Pathogens. D. Hornby, ed. CAB International, Wallingford, UK.

22. Leibinger, W., Breuker, B., Hahn, M., and Mendgen, K. 1997. Control of postharvest pathogens and colonization of the apple surface by antagonistic microorganisms in the field. Phytopathology 87:1103-1110.

23. Lers, A., Jiang, W. B., Lomaniec, E., and Aharoni, N. 1998. Proteins functionally and immunologically related to pathogenesis-related proteins are induced during parsley leaf senescence. Physiol. Plant Pathol. 103:497-502.

24. Lisker, N., Cohen, L., Chalutz, E., and Fuchs, Y. 1983. Fungal infections suppress ethylene-induced phenylalanine ammonia-lyase activity in grapefruit. Physiol. Plant Pathol. 22:331-338.

25. McCollum, T. G., Doostdar, H., Mayer, R. T., and McDonald, R. E. 1997. Characterization of chitinases and $\beta$-1,3-glucanases in grapefruit flavedo during fruit development. Physiol. Plant Pathol. 99:486-494.

26. Newbury, D. E., Joy, D. C., Echlin, P., Fiori, C. E., and Goldstein, J. I., eds. 1986. Advances In Scanning Electron Microscopy and X-Ray Microanalysis. Plenum Press, NY.

27. Porat, R., Weiss, B., Cohen, L., Daus, A., Goren, R., and Droby, S. 1999. Effects of ethylene and 1-methylcyclopropene on the postharvest qualities of 'Shamouti' oranges. Postharv. Biol. Technol. 15:155-163.

28. Roberts, R. G. 1990. Postharvest biological control of gray mold of apple by Cryptococcus laurentii. Phytopathology 80:526-530.

29. Rodov, V., Ben-Yehoshua, S., D'hallewin, G., and Castia, T. 1994. Accumulation of phytoalexins scoparone and scopoletin in citrus fruits subjected to various postharvest treatments. Acta Hortic. 381:517-523.

30. Stretch, A. W. 1989. Biological control of blueberry and cranberry fruit rots (Vaccinium corymbosu L. and Vaccinium macrocarpon Ait.). Acta Hortic. 241:301-306.

31. Teixidó, N., Viñas, I., Usall, J., and Magan, N. 1998. Control of blue mold of apples by preharvest application of Candida sake grown in media with different water activity. Phytopathology 88:960-964.

32. Wilson, C. L., Wisniewski, M. E., Droby, S., and Chalutz, E. 1993. A selection strategy for microbial antagonists to control postharvest diseases of fruits and vegetables. Sci. Hortic. 40:105-112.

33. Wisniewski, M., Biles, C., Droby, S., McLaughlin, R., Wilson, C., and Chalutz, E. 1991. Mode of action of the postharvest biocontrol yeast, Pichia guilliermondii. I. Characterization of the attachment to Botrytis cinerea. Physiol. Mol. Plant Pathol. 39:245-258. 